\title{
Factors Influencing Employees' Job Motivation: a Case Study of Small and Medium Enterprises in Dong Nai Province
}

\author{
Nguyen Thi Phuong Thao \\ *Corresponding Email: nguyenthiphuongthao24783@gmail.com
}

Dong Nai University, Vietnam

Received: November 5, 2020

Revised: November 16, 2020

Accepted: November 25, 2020

\begin{abstract}
The research explores the factors affecting employees' job motivation in small and medium enterprises in Dong Nai province from June 2019 to June 2020. The results of multiple linear regression analysis showed that there are five factors including the following elements: relationships in the organization; interesting job; Salary, bonus, and benefits; Training and promotion and assessment of job performance affects the working motivation of employees in small and medium-sized enterprises in Dong Nai province with the significance of $5 \%$. In addBesidesstudy results were processed from SPSS 20.0, Amos software. Estimated parameters of the model by the least least-squared with a significance level of $1 \%$. The results are also significant scientific evidence for researchers and policymakers at small and medium enterprises in Dong Nai province to apply research results to human resource development in the future. Based on the five-factor test results, the author proposed the priority governance implications that the author suggested in order of priority, respectively, interesting work, performance evaluation, organization, salary, bonus and welfare regime, and training and promotion.
\end{abstract}

Keywords: Motivation, Job, Work, Training, Promotion, DNU

\section{Introduction}

In recent years, working motivation significantly influences business organizations' operating efficiency, so creating an incentive is always interested in any organization. This factor considered as one of the critical functions of the manager, the factor that determines the performance and competitiveness of an organization, whether it is a state organization or a private organization in any country; creating motivation for employees is of particular importance because they are an essential part determining the effectiveness and efficiency of the organizational apparatus by Daneshkohan et al. (2015). Motivation affects the performance of individuals and organizations. This result is always real for any organization, but this is more important for production and business organizations because if the employee is not motivated to work or motivated to do is not favorable, it will affect. Performance of the organization and harms the efficiency of production and business activities.

Working motivation is the basis for creativity in the organization. Motivated people often feel comfortable and passionate about the assigned tasks. Therefore, they always show creativity at work, thereby helping the organization has more creative ideas, innovating, creating breakthroughs in the organization, and adapting to changes. And proactively make changes.

Therefore, in the face of practical as well as theoretical pressure, the author decides to choose the research topic and gives the research goal to explore the factors affecting the job motivation of employees in Small and medium-sized enterprises in Dong Nai province to

Copyright (C) 2020, Journal of Asian Multicultural Research for Economy and Management Study, 
contribute to solving shortcomings that exist in the practical operation on small and mediumsized enterprises in Dong Nai province.

\section{Literature Review}

\section{The concept of job motivation (JM)}

In the current period, the organization's human resources play a vital role, which is the decisive factor in its success or failure. Creating motivation is one of the critical contents of human resource management in the organization; it motivates employees to work enthusiastically to improve working productivity. There are many different notions about inspiring work, but they all have the most basic commonalities. According to Barzoki et al. (2012), "Labor dynamics are the employees' desire and volunteering to increase their efforts towards a certain goal or outcome."

According to Almobaireek \& Manolova (2013) showed that "Labor dynamics are the internal factors that stimulate people to actively work in conditions that allow for high productivity and efficiency. The manifestation of motivation is the willingness, effort, and passion for working to achieve the organization's goals and the employees themselves. Thus, we can see that work motivation is one factor that stimulates people to work hard to create productivity and efficiency.

Motivation to work motivates individuals to play their inner strengths and overcome challenges and difficulties to complete their work in the best way. Besides, the working motivation in each individual manifested by the positive working attitude and spirit also contributes to creating an effective working environment, stimulating the operational needs of Ashiqur et al. (2017).

\section{Relationship in the organization (RO)}

Employees will be more comfortable if superiors are friendly, approachable, fair, and integrity. The superior often encourages and encourages employees to work to create a pleasant feeling between the manager and the employee, then the employees will see their superiors as their relatives, as goals to strive and make efforts. Work harder to match their superiors' attention and help by Bryson \& White (2019). Besides, the support and help from colleagues when needed to employees also play an essential role. When they find a comfortable, friendly working or the relationship between employees is always relaxed and open, they will coordinate well at work; the work will be conducted smoothly by Sharma (2016). This factor shows that the relationship between colleagues also plays a vital role in creating motivation for employees. Therefore, the author suggests human capital in a research model on successful business startups in Vietnam. Thus, the following hypothesis was built.

Hypothesis H1: Relationship in the organization has a positive impact on employees' job motivation in small and medium enterprises in Dong Nai province.

\section{Interesting Job (IJ)}

The nature of work refers to the performance of the job and the type of work it is. A job can be repeated or altered, creative or monotonous, easy or difficult. A job is motivating if it has a variety of skills, the task's identity, the importance of the task, self-control, and feedback. Thus, to put it merely, interest in the job can be defined as the degree of positivity an individual has about his/her emotions or attitudes toward the job by Lorincová et al. (2019). When a person says that he is absorbed in his position, he likes and appreciates and feels good about his job. Employees interested in work often spend most of their time working and contributing to the organization. They also work with productivity and quality and be more

Copyright (C) 2020, Journal of Asian Multicultural Research for Economy and Management Study, Under the license CC BY-SA 4.0 
efficient, especially when performance is linked to rewards. Thus, the following hypothesis was built.

Hypothesis H2: Interesting job in the organization has a positive impact on employees' job motivation in small and medium enterprises in Dong Nai province.

\section{Salary, bonus, and benefits (SB)}

Income includes salaries, allowances, bonuses, benefits; the payment must be commensurate with the employee's ability and effort to contribute to the business if the income is not adequate. Creates dissatisfaction, reduces work effort and reduces motivation for the employee by Dominguez (2018). But if the managers know how to please employees by paying fair wages, matching the employee's performance, and the employee's actual ability, it may increase employee motivation. Since then, the staff will make more effort at work. Wages play an essential role for both workers and businesses. The salary has the effect of compensating for the labor force of the employees. Simultaneously, the salary also significantly impacts encouraging employees to work peacefully by Ellickson \& Logsdon (2001). Employees can only confidently put their best into their work if that job gives them enough money to cover their lives. In reality, wages are considered a significant measure of professional qualifications and seniority. Therefore, employees are very proud of their high salary. They want a raise, even though the wage can only make up a small part of their total income. Thus, the following hypothesis was built.

Hypothesis H3: Salary, bonus, and benefits in the organization have a positive impact on employees' job motivation in small and medium enterprises in Dong Nai province.

\section{Training and promotion (TP)}

The factor of training and advancement in the job is understood as development, it is a motivating factor for work, and therefore this factor should be considered as motivation factor at a high level by Kampf et al. (2017). Human resource training and development is one of the positive measures to increase businesses' resilience to the changing environment. Training and development provide enterprises with high-quality human capital to contribute to improving competitiveness. Training is considered a strategic weapon of the organization to improve competitiveness against competitors. Training is now considered an investment in the human capital of the organization by Muogbo (2013). Studies show that the effectiveness of newly trained employees is on par with experienced employees. At the same time, training creates a current and future source of competencies for the organization. There is growing economic evidence that investing in training is associated with long-term and sustainable returns for the organization. Thus, the following hypothesis was built.

Hypothesis H4: Training and promotion in the organization positively impact employees' job motivation in small and medium enterprises in Dong Nai province.

\section{Performance evaluation (PE)}

Performance evaluation should be used in the rating system, promoting internal endogenous behavior, including completing specific tasks specified in the assignment-work by McClean $\&$ Collins (2019). Evaluate the performance of an individual's position on an annual basis to know the individual's level of performance. At the same time, this is also a basis for emulation, reward, sending, training, and Promoting and promoting, appointing individuals to see their contributions recognized, encouraged, increasing the motivation to work more for the organization to create values for the organization function by McClelland \& David (2013). Thus, the following hypothesis was built. 
Hypothesis H5: Performance evaluation in the organization positively impacts employees' job motivation in small and medium enterprises in Dong Nai province.

Based on previous studies, the theory of relevance and the relationship between the factors affecting work motivation plus the relevant ideas mentioned above. The author built the research model as follows.

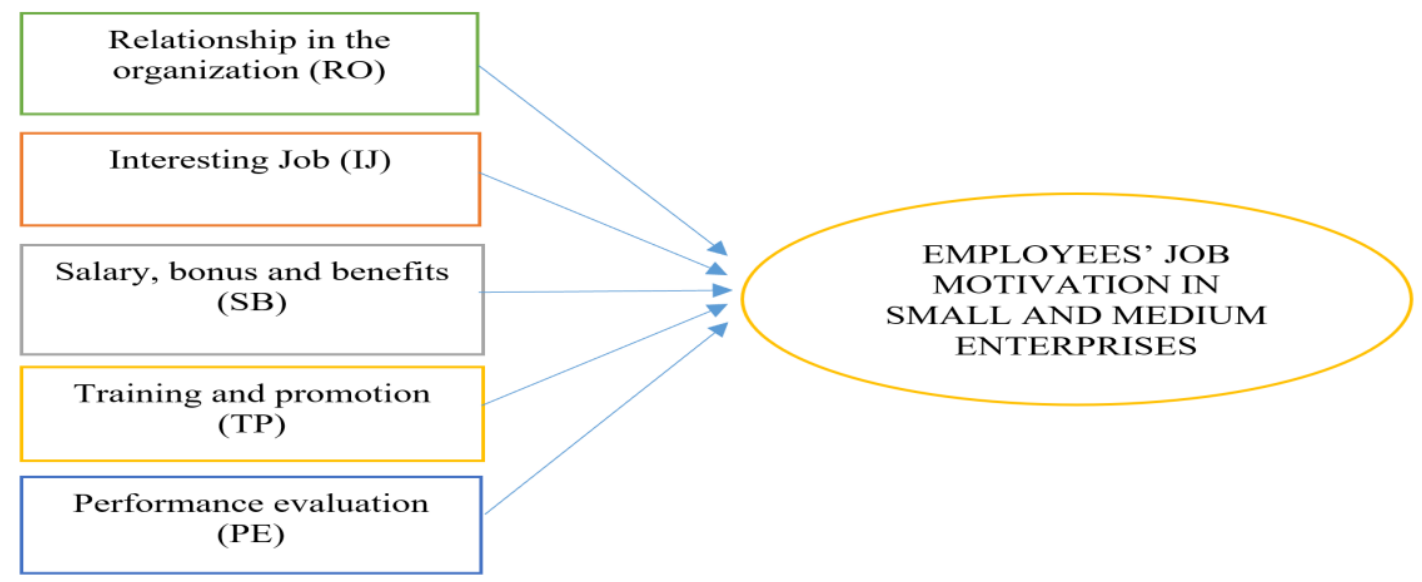

Figure 1. Research Model For Factors Influencing The Employees' Job Motivation In Small And Medium Enterprises In Dong Nai Province

\section{Methods}

In this paper, the author uses two research methods: qualitative research and quantitative research. The article is done through two steps: (1) preliminary research using qualitative methodologies to identify the factors affecting the motivation to work in small and medium enterprises in Dong Nai province, scale-up. (2) formal research using quantitative methods to evaluate the impact of the factor on work motivation from which there is a basis for concluding the problem, the ways explicitly presented through preliminary research and official research.

In this research paper, the author uses qualitative research methods through comments from 30 experts (including deputy heads of departments at small and medium enterprises in Dong Nai province, longtime workers. in the company) to make evaluation criteria based on the research of factors affecting work motivation of employees in small and medium enterprises in Dong Nai province. The author conducted to edit the model and build the questionnaire, if any.

In the official study, the author used quantitative methods to collect data, such as direct interviews, sending survey questionnaires according to the prepared form. After entering data, the author processed data with SPSS 20.0 and Amos software through the following steps:

Verify the reliability of variables with Cronbach's Alpha coefficients. The author has tested the scale's reliability through Cronbach's alpha coefficients; Cronbach's alpha will test the reliability of the variables used to measure each factor affecting work motivation. The sampling method plays a significant role in this study. According to the researchers, for factor analysis (EFA), the minimum sample size is $\mathrm{N}>5 * \mathrm{n}$ (n: Total number of observed variables). According to Tho et al. (2011), To conduct regression analysis as best as possible, the minimum sample size needed is calculated using the formula $\mathrm{N}>50+8 \mathrm{~m}$ (where $\mathrm{m}$ is the variable). 
The researchers tested Cronbach's Alpha, EFA, CFA, SEM. This method based on the eigenvalue, the appropriate factorial analysis, and the observed variables in the whole, which are correlated when Average Variance Extracted is $>50 \%$, the KMO coefficient is within 0.5 to 1 , Sig coefficient $\leq 5 \%$, the loading factors of all observed variables are $>0.5$. Also, the researchers tested exploratory factor analyses (EFA) were performed. The researchers tested the research model: the researchers specified the number of factors required in the data and which measured variable is related to which latent variable. Confirmatory factor analysis (CFA) is a tool used to confirm or reject the measurement theory by Hair et al. (1998). Chisquare testing is $\mathrm{P}$-value $>5 \% ; \mathrm{CMIN} / \mathrm{df} \leq 2$, some cases $\mathrm{CMIN} / \mathrm{df}$ maybe $\leq$ three or $<5$; GFI, TLI, CFI $\geq 0.9$ by Hair et al. (1998). However, according to recent researchers' opinions, GFI is still acceptable when it is more significant than 0.8; RMSEA $\leq 0.08$. Apart from the above criteria, the test results must also ensure the synthetic reliability $>0.6$; Average Variance Extracted must be greater than 0.5.

In this study, the author chose a large enough sample to satisfy both the criteria of the EFA factor study method and the multiple regression method. N> Max (sample size required by various regression), corresponding to the theoretical scale of 19 observed variables with five independent variable factors and one dependent variable (04 variables). Based on theory plus reality in Small and Medium Enterprises in Dong Nai Province, the author must investigate at least 115 votes $(23 \times 5)$ by Hair et al. (1998).

The author distributes 500 quétionaires to 500 employees, direct interviews with employees in small and medium enterprises in Dong Nai province. The results received 465 responses from direct talks. After selecting, checking, there are 35 unsatisfactory votes due to lack of information, so the author has recovered 465 valid answers. Thus, these 465 right answer sheets are officially processed in the research paper by the software SPSS 20.0 and Amos. Finally, the researchers had conclusions of the research, and the researchers had recommendations.

\section{Results and Discussion}

The authors support the scale reliability tests for various factors affecting the employees' job motivation in small and medium enterprises in Dong Nai province.

Table 1. The Scale Reliability Tests for Various Factors Affecting the Employees' Job Motivation in Small and Medium Enterprises in Dong Nai Province

\begin{tabular}{|c|l|c|}
\hline Items & \multicolumn{1}{|c|}{ Content } & $\begin{array}{c}\text { Cronbach's } \\
\text { Alpha if Item } \\
\text { Deleted }\end{array}$ \\
\hline \multirow{2}{*}{ RO1 } & $\begin{array}{l}\text { Your colleagues respected your proposal in a small and medium enterprise } \\
\text { (SMEs) }\end{array}$ & 0.909 \\
\hline RO2 & Relations in SMEs are amicable and close to each other at work & 0.936 \\
\hline \multirow{2}{*}{ RO3 } & $\begin{array}{l}\text { Colleagues SMEs in Dong Nai province support and often help you solve } \\
\text { work when you have problems. }\end{array}$ & 0.943 \\
\hline RO4 & The superiors often support and help you with your work & 0.914 \\
\hline \multicolumn{2}{|c|}{ Cronbach's Alpha for the relationship in the organization (RO) } & $\mathbf{0 . 9 4 3}$ \\
\hline IJ1 & Your job is comfortable and able to handle work by yourself at SMEs & 0.815 \\
\hline IJ2 & You are empowered according to your abilities at the workplace in SMEs & 0.817 \\
\hline IJ3 & Your job is following your capacity and working time in SMEs & 0.848 \\
\hline IJ4 & Your job is to create and innovate experience in SMEs freely & 0.812 \\
\hline \multicolumn{2}{|c|}{ Cronbach's Alpha for interesting Job (IJ) } & $\mathbf{0 . 8 6 1}$ \\
\hline SB1 & LTPL1: Your current salary is consistent with your ability in SMEs & 0.927 \\
\hline SB2 & LTPL2: You are usually rewarded fairly for completing your job in SMEs & 0.942 \\
\hline
\end{tabular}

Copyright (C 2020, Journal of Asian Multicultural Research for Economy and Management Study, Under the license CC BY-SA 4.0 


\begin{tabular}{|c|l|c|}
\hline SB3 & $\begin{array}{l}\text { LTPL3: Good policy on welfare benefits for learning to improve } \\
\text { qualifications and results of work in SMEs in Dong Nai province }\end{array}$ & 0.943 \\
\hline SB4 & LTPL4: Good policy on high bonuses due to good results at work in SMEs & 0.924 \\
\hline \multicolumn{1}{|c|}{ Cronbach's Alpha for salary, bonus, and benefits (SB) } & $\mathbf{0 . 9 5 0}$ \\
\hline TP1 & SMEs bring opportunities for you to develop individual abilities. & 0.866 \\
\hline TP2 & $\begin{array}{l}\text { SMEs give you a good opportunity to improve your skills through short and } \\
\text { long term classes. }\end{array}$ & 0.824 \\
\hline TP3 & $\begin{array}{l}\text { You always receive enthusiastic help from colleagues and superiors in career } \\
\text { development }\end{array}$ & 0.875 \\
\hline \multicolumn{1}{|c|}{ Cronbach's Alpha for training and promotion (TP) } \\
\hline PE1 & $\begin{array}{l}\text { Criteria to evaluate the results of working in SMEs correctly reflect your } \\
\text { work results. }\end{array}$ & $\mathbf{0 . 8 9 9}$ \\
\hline PE2 & Your working results are assessed transparently and clearly by SMEs & 0.921 \\
\hline PE3 & Your SMEs regularly organizes comments to improve working efficiency. & 0.942 \\
\hline PE4 & $\begin{array}{l}\text { Your SMEs regularly organizes lessons to learn from experience to improve } \\
\text { working efficiency }\end{array}$ & 0.934 \\
\hline & \multicolumn{1}{|c|}{ Cronbach's Alpha for performance evaluation (PE) } & 0.914 \\
\hline JM1 & You are willing to work for a long time in SMEs & $\mathbf{0 . 9 4 5}$ \\
\hline JM2 & You believe in placing employees' obligations above their interests in SMEs & 0.844 \\
\hline JM3 & You always feel the spirit of working in SMEs & 0.789 \\
\hline & $\begin{array}{l}\text { You are willing to cooperate with your colleagues and give suggestions to } \\
\text { your superiors so that small and medium enterprises in Dong Nai province } \\
\text { can fulfill their tasks }\end{array}$ & 0.858 \\
\hline & Cronbach's Alpha for employees' job motivation (JM) & 0.800 \\
\hline
\end{tabular}

Source: The researchers' collecting data and SPSS 20.0

Table 1 showed that various factors affecting the employees' job motivation in small and medium enterprises in Dong Nai province had 23 variables surveyed corrected item-total correlation greater than 0.3 and Cronbach's Alpha if Item deleted greater than 0.6. So, the data is perfect for the next steps.

Table 2. Total Variance Explained

\begin{tabular}{|c|c|c|c|c|c|c|c|}
\hline \multirow{2}{*}{$\begin{array}{c}\text { Compone } \\
\text { nt }\end{array}$} & \multicolumn{3}{|c|}{ Initial Eigenvalues } & \multicolumn{3}{c|}{$\begin{array}{c}\text { Extraction Sums of Squared } \\
\text { Loadings }\end{array}$} & $\begin{array}{c}\text { Rotation Sums of } \\
\text { Squared Loadings }\end{array}$ \\
\cline { 2 - 8 } & Total & $\begin{array}{c}\text { \% of } \\
\text { Variance }\end{array}$ & $\begin{array}{c}\text { Cumulative } \\
\%\end{array}$ & Total & $\begin{array}{c}\text { \% of } \\
\text { Variance }\end{array}$ & $\begin{array}{c}\text { Cumulative } \\
\%\end{array}$ & Total \\
\hline 1 & 5.954 & 25.888 & 25.888 & 5.954 & 25.888 & 25.888 & 4.527 \\
\hline 2 & 3.599 & 15.647 & 41.535 & 3.599 & 15.647 & 41.535 & 3.568 \\
\hline 3 & 3.473 & 15.101 & 56.636 & 3.473 & 15.101 & 56.636 & 3.656 \\
\hline 4 & 2.562 & 11.139 & 67.775 & 2.562 & 11.139 & 67.775 & 4.198 \\
\hline 5 & 1.735 & 7.543 & 75.317 & 1.735 & 7.543 & 75.317 & 3.006 \\
\hline 6 & 1.313 & 5.710 & 81.028 & 1.313 & 5.710 & 81.028 & 4.051 \\
\hline$\ldots$ & $\ldots$ & $\ldots$ & $\ldots$ & & & & \\
\hline 23 & .026 & .112 & 100.000 & & & & \\
\hline
\end{tabular}

Source: The researchers' collecting data and SPSS 20.0

Table 2 showed that extraction sums of squared loadings of Cumulative \% are $81.028 \%$ $(>60 \%)$, and Initial Eigenvalues is $1.313(>1)$. This result is suitable for the next step.

Table 3. Kmo and Bartlett's Test for Various Factors Affecting the Employees' Job Motivation in Small and Medium Enterprises in Dong Nai Province

\begin{tabular}{|l|c|}
\hline Code & Component \\
\hline
\end{tabular}

Copyright (C) 2020, Journal of Asian Multicultural Research for Economy and Management Study, Under the license CC BY-SA 4.0 


\begin{tabular}{|c|c|c|c|c|c|c|}
\hline & 1 & 2 & 3 & 4 & 5 & 6 \\
\hline PE4 & .944 & & & & & \\
\hline PE2 & .934 & & & & & \\
\hline PE1 & .932 & & & & & \\
\hline PE3 & .870 & & & & & \\
\hline SB4 & & .947 & & & & \\
\hline SB1 & & .937 & & & & \\
\hline SB2 & & .927 & & & & \\
\hline SB3 & & .919 & & & & \\
\hline RO1 & & & .953 & & & \\
\hline RO4 & & & .950 & & & \\
\hline $\mathrm{RO} 2$ & & & .903 & & & \\
\hline RO3 & & & .895 & & & \\
\hline JM4 & & & & .900 & & \\
\hline JM2 & & & & .854 & & \\
\hline JM1 & & & & .847 & & \\
\hline JM3 & & & & .736 & & \\
\hline IJ4 & & & & & .859 & \\
\hline IJ1 & & & & & .848 & \\
\hline IJ2 & & & & & .845 & \\
\hline IJ3 & & & & & .812 & \\
\hline TP3 & & & & & & .930 \\
\hline TP2 & & & & & & .930 \\
\hline TP1 & & & & & & .825 \\
\hline
\end{tabular}

Source: The researchers' collecting data and SPSS 20.0

Table 3 showed that the KMO coefficient is 0.814 , and the level of significance (Sig) is 0.000 . The result showed that there are six components. Extraction sums of squared loadings are $\%$ of the Variance coefficient is 81.028 , with the level of significance (Sig) is 0.000 .

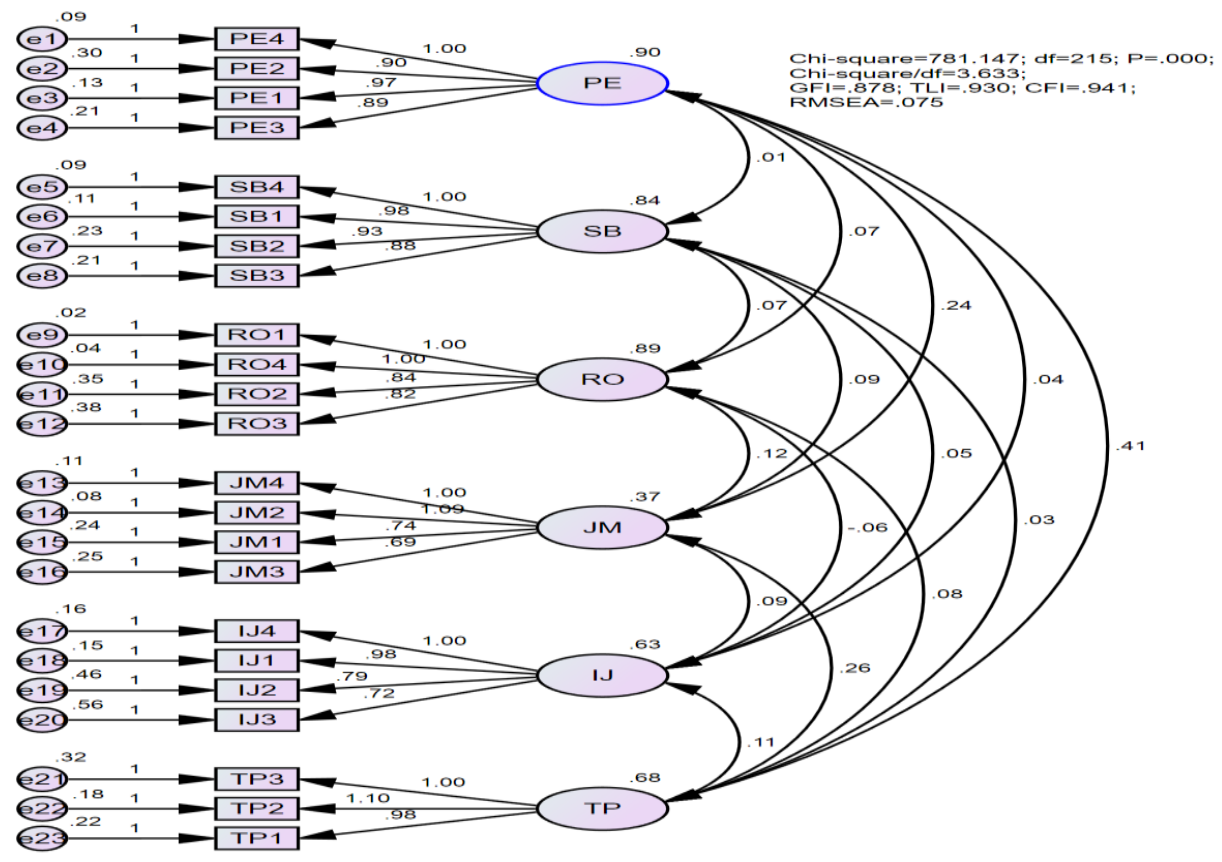

Figure 2. Confirmatory Factor Analysis for Factor Affecting the Employees' Job Motivation in Small and Medium Enterprises in Dong Nai Province

Copyright (C 2020, Journal of Asian Multicultural Research for Economy and Management Study, Under the license CC BY-SA 4.0 
Source: The researchers' collecting data, SPSS 20.0 and Amos

Table 4. Coefficients From Structural Equation Modelling (SEM)

\begin{tabular}{|l|l|l|c|c|c|c|c|c|}
\hline \multicolumn{2}{|c|}{ Relationships } & Coefficient & $\begin{array}{c}\text { Standardized } \\
\text { Coefficient }\end{array}$ & S.E & C.R. & P & Conclusion \\
\hline JM & $<---$ & RO & .060 & .120 & .021 & 2.843 & .004 & H3: Supported \\
\hline JM & $<---$ & IJ & .076 & .124 & .026 & 2.878 & .004 & H2: Supported \\
\hline JM & $<---$ & TP & .221 & .374 & .036 & 6.101 & $* * *$ & H1: Supported \\
\hline JM & $<---$ & PE & .094 & .203 & .025 & 3.733 & $* * *$ & H5: Supported \\
\hline JM & $<---$ & SB & .061 & .125 & .021 & 2.934 & .003 & H4: Supported \\
\hline
\end{tabular}

Note: $* * *$ Significant at 1.0 percent (All t-tests are one-tailed)

Source: The researchers' collecting data, SPSS 20.0 and Amos

Table 4 showed that column "P" $<0.01$ with significance level 0.01 and column "Conclusion" showed that all of the hypotheses are accepted.

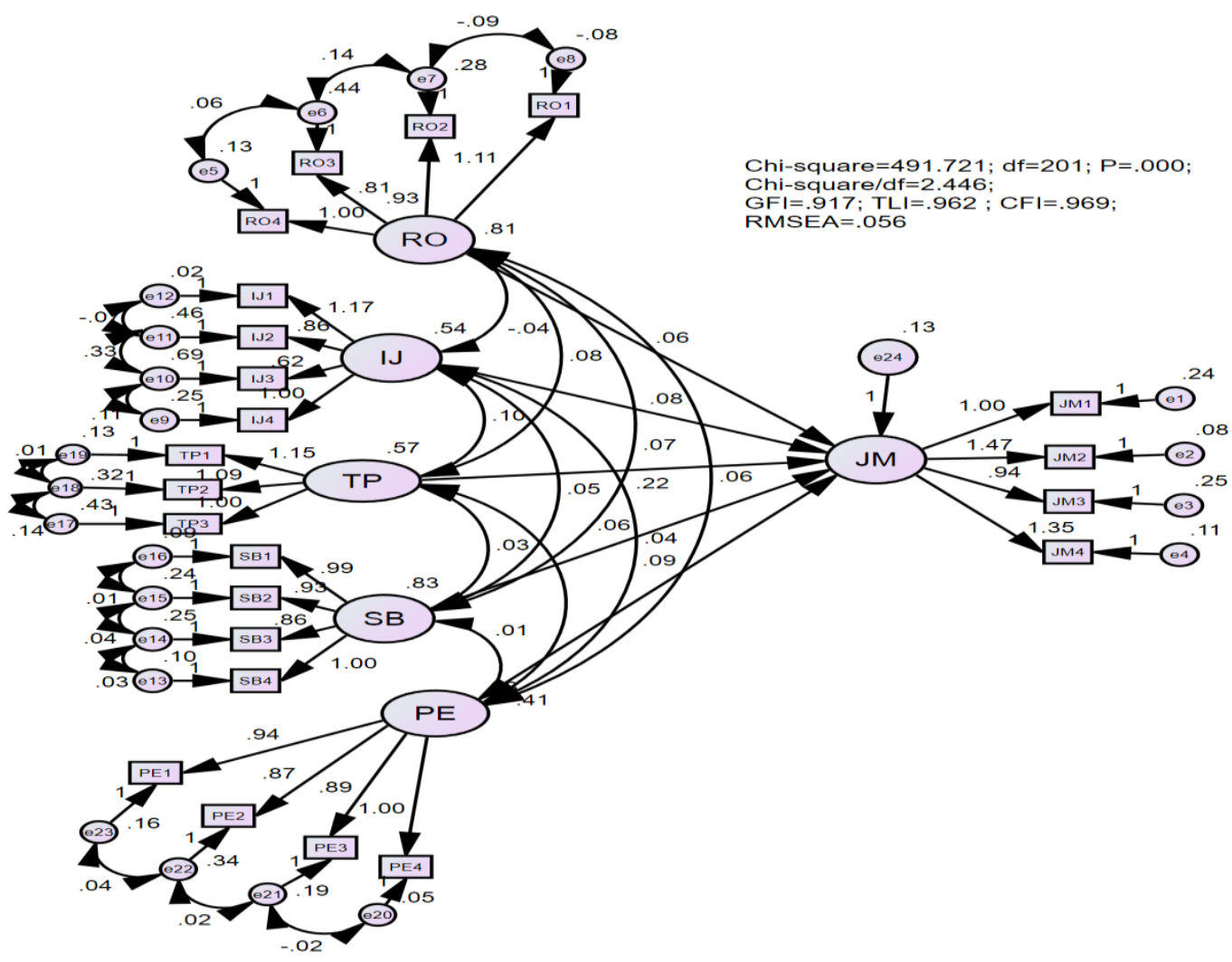

Figure 3. The Structural Model Showing The Structural Linkage Between Components

Source: The researchers' collecting data and Amos

The managerial implication for training and promotion $(\boldsymbol{\beta}=\mathbf{0 . 3 7 4})$ had the most substantial impact on employees' job motivation in small and medium enterprises in Dong Nai province with a significance level of $1 \%$. The reality shows that the current workforce lacks stability works unprofessionally, and is not on par with the task's requirements. The fact shows that many qualified and skilled workers are still inadequate, limited understanding of the law, administration, job execution skills, and the ability to apply modern science and technology. For that reason, small and medium enterprises in Dong Nai province need to renovate training and retraining workers to build a team that meets immediate and long-term requirements. 
The managerial implication for performance evaluation $(\boldsymbol{\beta}=\mathbf{0 . 2 0 3})$ had the second impact on employees' job motivation in small and medium enterprises in Dong Nai province with a significance level of $1 \%$. Performance evaluation is often understood as a systematic, formal, and public measurement of work performance against the set standards. The employee assessment needs to be done regularly and reasonably, which will create a basis for suitable employee organization solutions. Therefore, it is necessary to continue to innovate the labor assessment, building and completing professional title standards, job positions specific evaluation criteria for each title, position.

The managerial implication for salary, bonus, and welfare $(\boldsymbol{\beta}=\mathbf{0 . 1 2 5})$ had the third impact on employees' job motivation in small and medium enterprises in Dong Nai province with the significance level of $1 \%$. The salary policy still has many limitations and shortcomings. Wage policy in the public sector is always complicated, the payroll system design is not suitable for the job position, title and leadership situation; It is also heavy on average, cannot ensure life, has not promoted talents, has not created a motivation to improve the quality and working efficiency of employees. Salary is the issue that employees are first concerned about when working. Therefore, building a good, fair, and scientific remuneration regime to motivate employees to work is the company's top priority.

The managerial implication for the interesting job $(\boldsymbol{\beta}=\mathbf{0 . 1 2 4})$ had the fourth impact on employees' job motivation in small and medium enterprises in Dong Nai province with a significance level of $1 \%$. Interesting job: Every worker has a particular ability. Therefore, if they assign them to jobs that match their abilities, they will enjoy and complete that job well. Thus, an organization needs staffing that can be understood as an essential job with a close relationship with the organizational structure. If you know how to find, arrange, use, and promote these talents, the effect will be significant in the future. Leaders should assign jobs to employees comfortably and handle jobs well at small and medium enterprises in Dong Nai province.

The managerial implication for a relationship in the organization $(\boldsymbol{\beta}=\mathbf{0 . 1 2 0})$ had the least impact on employees' job motivation in small and medium enterprises in Dong Nai province with the significance level of $1 \%$. Relationship in an organization is the relationship between employees in an organization, it has a very important meaning, contributing to improving employees' working motivation. More and more people realize the power of relationships, which comes from good communication skills. The employee must be proficient in oral and written communication. Workers must know how to impress their voice, body language, eyes, and expressions that are easy to understand and persuade. Contracts available today depend a lot on bargaining power. Good communication ability also effective in human resource management.

\section{Conclusion}

According to the survey results from 500 employees in small and medium enterprises in Dong Nai province, 465 workers were validly answered in small and medium enterprises in Dong Nai province. After assessing the reliability of the scale through Cronbach's Alpha coefficients and analyzing the discovery factors EFA, the results showed that there are five factors, including relationship in the organization (RO), Interesting Job (IJ), Salary, bonus, and welfare (SB); Training and promotion (TP); performance evaluation (PE). All five factors affected employees' job motivation in small and medium enterprises in Dong Nai province with a significance level of $1 \%$. Besides, the study results were processed from SPSS 20.0 software. Estimated parameters of the model by the least square's method with a significance level of $1 \%$. Besides, the results are also important and scientific evidence for 
researchers and policymakers for employees at SMEs in Dong Nai province to apply the results research for the development of human resources in the future

\section{References}

Almobaireek, W. N., \& Manolova, T. S. (2013). Entrepreneurial motivations among female university youth in Saudi Arabia. Journal of Business Economics and Management, 14(sup1), S56-S75.

Ashiqur R., Noor Saadah Zainal A. and Md Mahadhi H. (2017). Factors affecting employees' motivation at infrastructure University Kuala Lumpur. Southeast Asia Journal of Contemporary Business, Economics, and Law, 17(2), 1-8.

Barzoki, A. A., Attafar, A., \& Jannati, A. R. (2012). An analysis of factors affecting the employees motivation based on Herzberg's hygiene factors theory (The Study Golpayegan City Saipa Corporation Industrial Complex's Staff). Australian Journal of Basic and Applied Sciences, 6(8), 115-123.

Bryson, A., \& White, M. (2019). HRM and small-firm employee motivation: Before and after the great recession. ILR Review, 72(3), 749-773.

Daneshkohan, A., Zarei, E., Mansouri, T., Maajani, K., Ghasemi, M. S., \& Rezaeian, M. (2015). Factors affecting job motivation among health workers: a study from Iran. Global journal of health science, 7(3), 153.

Dominguez, N. (2018). SME internationalization strategies: Innovation to conquer new markets. John Wiley \& Sons.

Lorincová, S., Štarchoň, P., Weberová, D., Hitka, M., \& Lipoldová, M. (2019). Employee motivation as a tool to achieve sustainability of business processes. Sustainability, 11(13), 3509.

Ellickson, M. C., \& Logsdon, K. (2001). Determinants of job satisfaction of municipal government employees. State and Local Government Review, 33(3), 173-184.

Hair, J. F., Black, W. C., Babin, B. J., Anderson, R. E., \& Tatham, R. L. (1998). Multivariate data analysis (Vol. 5, No. 3, pp. 207-219). Upper Saddle River, NJ: Prentice hall.

Kampf, R., Lorincova, S., Kapustina, L. M., \& Lizbetinova, L. (2017). Motivation level and its comparison between senior managers and blue-collar workers in small and medium-sized transport enterprises. Communications-Scientific letters of the University of Zilina, 19(4), 43-49.

McClean, E., \& Collins, C. J. (2019). Expanding the concept of fit in strategic human resource management: An examination of the relationship between human resource practices and charismatic leadership on organizational outcomes. Human Resource Management, 58(2), 187-202.

McClelland \& David C. (2013), Human Motivation Theory, Mind Tools, Ltd. Retrieved.

Muogbo, U. S. (2013). The impact of employee motivation on organisational performance (a study of some selected firms in anambra state nigeria). The international journal of engineering and science, 2(7), 70-80.

Sharma, D. (2015). A Study on Employee Motivation in Private School: A Case of Bethany Boarding Higher Secondary School (BHSS) Pokhara. Journal of Nepalese Business Studies, 9(1), 91-101. 